\title{
KONSEP SOSIAL BUDAYA HUBUNGAN MANUSIA DALAM PEMBENTUKAN KATA MAJEMUK BAHASA JEPANG
}

\author{
Rizki Dwi Cahyo, Masilva Raynox Mael \\ Universitas Negeri Surabaya, rizkicahyo@mhs.unesa.ac.id \\ Universitas Negeri Surabaya, masilvamael@unesa.ac.id
}

\begin{abstract}
ABSTRAK
Terdapat berbagai faktor yang mendasari pembentukan dan pemakaian bahasa oleh masyarakat penuturnya. Hal ini dikarenakan hubungan erat yang tak bisa dipisahkan antara bahasa dan masyarakat. Hubungan tersebut adalah (1) Bahasa mempengaruhi masyarakat, (2) Masyarakat mempengaruhi bahasa, dan (3) Saling berpengaruhnya bahasa dan masyarakat. Pengaruh tersebut satu diantaranya tampak pada pembentukan fukugougo atau komposisi kata majemuk Bahasa Jepang yang tidak semena-mena terbentuk begitu saja namun terdapat pengaruh dari konsep sosial budaya masyarakat Jepang dalam pembentukannya. Konsep masyarakat yang mempengaruhi tersebut adalah sistem stratifikasi, sistem keluarga, dan sistem jenis kelamin (gender). Pada kesempatan kali ini penulis akan memaparkan fukugougo yang terpengaruh oleh konsep sosial budaya di atas yang terdapat pada buku minna no nihongo Shokyuu I dan II, dan juga akan memaparkan bentuk variasi komposisi pemajemukannya.
\end{abstract}

Kata kunci: fukugougo, sosial budaya, komposisi

\section{PENDAHULUAN}

Mempelajari suatu bahasa identik dengan mempelajari kosakata. Kosakata merupakan unsur yang sangat penting dalam masyarakat yang menggunakan bahasa, karena dengan menggunakan kata-katalah manusia berbahasa. Pembelajar suatu bahasa tertentupun memiliki kecenderungan untuk mempelajari dan meperdalam penguasaan kosakata atau perbendaharaan katanya terlebih dahulu dan kemudian baru mempelajari tata bahasanya. Bidang kajian linguistik yang mempelajari bentuk dan pembentukan kata tersebut dinamakan morfologi (Chaer 
Rizki Dwi Cahyo dan Masilva Raynox Mael, Konsep Sosial... (hlm. 210-222)

dalam Jayanti). Dalam berbagai macam proses pembentukan kata terdapat proses yang disebut komposisi atau pemajemukan. Komposisi atau pemajemukan merupakan penggabungan morfem dasar dengan morfem dasar baik yang bebas maupun terikat. Hasil pemajemukan dapat memiliki identitas leksikal (makna) yang sama dengan komponen pembentuknya, berbeda, atau bahkan identitas baru. Kata yang terbentuk dari proses komposisi itulah yang dinamakan kata majemuk (Chaer, 2007: 185).

Kata majemuk disebut dengan fukugougo dalam bahasa Jepang. Konstruksinya dapat berupa penggabungan kata yang masing-masing memiliki kelas kata yang sama seperti meishi (nomina) + meishi (nomina), ataupun dari kata yang masing-masing memiliki kelas kata yang berbeda seperti keiyoshi (adjektiva) + doushi $($ verba). Namun tidaklah semua kelas kata ataupun kata dapat mengalami proses komposisi dan membentuk kata majemuk. Seperti yang sudah penulis sampaikan sebelumnya bahwa makna yang terbentuk dapatlah berasal dari kata pembentuknya maupun tidak dihasilkan dari kata pembentuknya sama sekali (Jayanti).

Terdapat tiga kelompok variasi komposisi kata majemuk bahasa Jepang, yaitu native compound, sino-japanese compund, dan hybrid compund (Shibutani dalam Jayanti). Native compound adalah penggabungan kata yang merupakan kata bahasa Jepang asli. Kata bahasa Jepang asli yang dimaksudkan adalah kata bahasa Jepang yang cara pelafalannya menggunakan cara baca Kunyomi. Kata majemuk native compound memiliki komposisi yaitu semua kata pembentuknya dibaca dengan cara baca kunyomi yang kemudian mengalami penggabungan. Contohnya seperti kata 赤色(akairo). Sebaliknya, kata majemuk sino-japanese compund memiliki kata pembentuk yang menggunakan cara baca dari china atau onyomi dalam komposisinya. Seperti contohnya adalah kata 男子(danshi). Variasi kata 
majemuk yang terakhir yaitu hybrid compound memiliki kata pembentuk dengan cara baca gabungan yaitu satu menggunakan kunyomi dan satu lainnya menggunakan cara baca onyomi. Contohnya seperti 団子(dango).

Dari pemaparan di atas dapat diketahui bahwa fukugougo tidak dapat terbentuk dengan begitu saja, namun terdapat beberapa faktor yang dapat mempengaruhi pembentukanya seperti, faktor fonologis, faktor ikonik, dan juga faktor sosial budaya masyarakat penuturnya. Namun, yang akan penulis coba untuk bahas dan paparkan kali ini adalah kata majemuk yang dipengaruhi oleh konsep sosial budaya masyarakat di Jepang saja. Bagian dari linguistik yang memperlajari Bahasa dan masyarakat disebut Sosiolinguistik. Bahasa dan masyarakat penuturnya merupakan dua hal yang tidak dapat dipisahkan. Terdapat setidak-tidaknya tiga hubungan antara masyarakat dan bahasa yaitu (1) Bahasa mempengaruhi masyarakat, (2) Masyarakat mempengaruhi bahasa, dan (3) Bahasa dan masyarakat saling mempengaruhi satu sama lain (Wijana dan Muhammad, 2006). Berbicara mengenai bahasa yang merupakan sebuah alat untuk masyarakat saling berkomunikasi dan berinteraksi, tidak dapat terlepas dari kebudayaan dan norma-norma yang berlaku dalam suatu masyarakat. Pada masyarakat yang memiliki variasi tingkat sosial, akan menghasilkan bahasa yang berhubungan dengan adanya variasi tingkat sosial tersebut dan juga memiliki keragaman bahasa sesuai dengan keragaman masyarakatnya. Pada masyarakat yang terdapat perbedaan kondisi sosial antara pria dan wanita juga akan timbul ragam atau variasi bahasa yang berbeda juga antara pria dan wanita.

Sama halnya dengan masyarakat berbahasa lainnya, juga terdapat faktor sosial budaya yang mempengaruhi atau bahkan mendasari lahirnya bahasa dan pemakaian bahasa oleh masyarakat Jepang. Bangsa Jepang pada zaman dahulu merupakan kelompok masyarakat yang terdapat stratifikasi di dalamnya. Selain kelas-kelas sosial, juga terdapat konsep sosial lainya seperti keluarga, jenis 
Rizki Dwi Cahyo dan Masilva Raynox Mael, Konsep Sosial... (hlm. 210-222)

kelamin, dan usia yang dapat mempengaruhi bahasa khususnya pada pembentukan kata.

Sistem stratifikasi

Terdapat 4 golongan masyarakat di Jepang pada jaman kamakura, yaitu bushi (golongan prajurit), noumin (golongan petani), kouin (golongan pegawai), dan shounin (golongan pedagang). Pada jaman tersebut golongan kouin dan shoumin merupakan golongan yang memiliki kasta rendah. Berawal dari stratifikasi yang ada itulah hubungan antar manusia di Jepang pada umumnya menganut azas hubungan vertikal yang sangat kental. Masyarakat Jepang sangat memperhatikan posisi mereka di dalam kelompok sosial dan mereka pun bersikap, bertindak, berkebiasaan, dan beretos kerja atas dasar pengaruh struktur masyarakat yang menggunakan sistem hubungan atas bawah tersebut.

Hubungan atasan dan bawahan, bos dan anak buah, penguasa dan rakyat, senior dan yunior. Hubungan seperti ini bagi orang jepang adalah sesuatu yang haruslah dipertahankan untuk menjaga dan memelihara kepatuhan, penghormatan, dan disiplin kerja. Namun meskipun begitu, hubungan senioritas ini tidaklah dianggap sebagai sikap yang arogan melainkan pembelajaran yang harus dipatuhi secara moral. Bukanlah berdasarkan pada usia, namun hubungan ini berdasarkan siapa yang terlebih dahulu memasuki atau memahami suatu bidang (pekerjaan), yang lebih dulu itulah yang akan dianggap sebagai senior (eribolot.weebly.com).

Sistem keluarga

Keluarga merupakan dasar dari unit sosial di Jepang. Cukup sama dengan di Indonesia, ayah sebagai kepala keluarga memegang kekuasaan lebih besar daripada Ibu. Inilah yang merupakan dasar dari konsep masyarakat yang dimana pria lebih unggul daripada wanita yang sampai sekarangpun masih berakar di dalam masyarakat Jepang dan sangat tercermin dalam sistem keluarga dengan 
dominasi peran dan kekuasaan ayah dalam keluarga (Minami, 1993: 155). Selain ayah, keluarga Jepang yang menganut paham patriarkal jugalah memiliki sistem yang menitik beratkan kepada peran dan tanggung jawab anak yang paling tua. Sejak zaman meiji, anak lelaki tertua di dalam keluarga mewarisi hak dan kewajiban untuk mengurus keluarga setelah ayah (Kodansha internasional dalam library.binus.ac.id).

Sistem pria dan wanita (Gender)

Jepang dahulu memiliki konsep masyarakat yang memisahkan kerja antara pria dan wanita. hal ini dikarenakan kuatnya pola fikir masyarakat bahwa wanita tidaklah boleh lebih superior daripada pria yang lebih kuat dan sebagai kepala keluarga. Pada zaman meiji (1868-1912) yang masih kental dengan diskriminasi gender yaitu pengaruh dari era Shogun Tokugawa. Pada zaman ini banyak kondisi sosial yang merendahkan martabat wanita. Dalam sistem keluarga (ie), sebagai wanita mustahil untuk mendapatkan harta warisan apabila masih terdapat anak lelaki di keluarganya tersebut. Untuk riwayat jodohpun demikian, wanita tidak dapat berpendapat dan membantah mengenai pemilihan pasangan hidupnya, seluruhnya ditentukan oleh kepala keluarga. Pada saat wanita hanya dapat menghasilkan keturunan perempuan pun, sang suami berhak untuk mengambil selir sampai dia dapat memiliki keturunan laki-laki sebagai ahli waris. Kedudukan selir dan keturunan laki-laki tersebut bahkan lebih tinggi dibandingkan keturunan perempuan dari istri yang sah.

Berdasarkan teori di atas penulis mencoba memaparkan fukugougo atau kata majemuk bahasa Jepang yang dirasa dalam pembentukannya terdapat pengaruh dari konsep atau faktor sosial budaya hubungan manusia masyarakat Jepang. Untuk data yang digunakan adalah kosakata yang diambil dari buku Minna no nihongo shokyuu I dan II.

\section{Metode}

214 | http://journal.unesa.ac.id/index.php/paramasastra 
Rizki Dwi Cahyo dan Masilva Raynox Mael, Konsep Sosial... (hlm. 210-222)

Penulis menggunakan sumber data berupa dari buku Minna no nihongo shokyuu I dan II. Data yang dikumpulkan berupa daftar kosakata majemuk di dalam buku yang menurut penulis mendapatkan pengaruh dari konsep sosial budaya Jepang dalam pembentukannya. Teknik pengambilan data yang penulis gunakan adalah teknik catat yaitu dengan membaca kemudian mencatat kosakata yang ditemukan dalam buku. Data yang didapat kemudian dipaparkan lebih lanjut dan terakhir ditarik kesimpulan berdasarkan hasil pemaparan yang dilakukan.

\section{PEMBAHASAN}

Hasil

Penulis mendapatkan total 7 data kata majemuk yang mendapatkan pengaruh dari konsep sosial budaya masyarakat Jepang dalam komposisinya. Kemudian penulis mencoba menglasifikasikan data yang didapat berdasarkan variasi komposisi kata majemuk dan sistem sosial budaya hubungan manusia yang mempengaruhinya sebagai berikut

\begin{tabular}{|l|l|l|l|}
\hline No & Fukugougo & $\begin{array}{l}\text { Konsep } \\
\text { Sosial } \\
\text { Budaya }\end{array}$ & $\begin{array}{l}\text { Variasi } \\
\text { Komposisi Kata } \\
\text { Majemuk }\end{array}$ \\
\hline 1 & 夫婦 Fuufu & $\begin{array}{l}\text { Sistem } \\
\text { Keluarga }\end{array}$ & $\begin{array}{l}\text { Sino-Japanese } \\
\text { Compound }\end{array}$ \\
\hline 2 & 兄弟 Kyoudai & $\begin{array}{l}\text { Sistem } \\
\text { Keluarga }\end{array}$ & $\begin{array}{l}\text { Sino-Japanese } \\
\text { Compound }\end{array}$ \\
\hline 3 & 親分 Oyabun & $\begin{array}{l}\text { Sistem } \\
\text { Stratifikasi }\end{array}$ & $\begin{array}{l}\text { Hybrid } \\
\text { Compound }\end{array}$ \\
\hline 4 & 子分 Kobun & $\begin{array}{l}\text { Sistem } \\
\text { Stratifikasi }\end{array}$ & $\begin{array}{l}\text { Hybrid } \\
\text { Compound }\end{array}$ \\
\hline
\end{tabular}




\begin{tabular}{|l|l|l|l|}
\hline 5 & $\begin{array}{l}\text { 大丈夫 Daijoubu } \\
\text { Gender }\end{array}$ & $\begin{array}{l}\text { Sistem } \\
\text { Compound }\end{array}$ \\
\hline 6 & $\begin{array}{l}\text { 先輩後輩 } \\
\text { SenpaiKohai }\end{array}$ & $\begin{array}{l}\text { Sistem } \\
\text { Stratifikasi }\end{array}$ & $\begin{array}{l}\text { Sino-Japanese } \\
\text { Compound }\end{array}$ \\
\hline 7 & 男女 Danjo & $\begin{array}{l}\text { Sistem } \\
\text { Gender }\end{array}$ & $\begin{array}{l}\text { Sino-Japanese } \\
\text { Compound }\end{array}$ \\
\hline
\end{tabular}

\section{A. 夫婦 / Fuufu}

Kata $f u u f u$ terbentuk dari dua huruf kanji yaitu 夫yang memiliki makna suami dan huruf 婦 yang memiliki makna istri. Fuufu tergolong dalam variasi kata majemuk bahasa Jepang sino-japanese compound karena kedua kata pembentuknya masing-masing dibaca dengan menggunakan cara baca cina atau onyomi. Huruf 夫dibaca dengan $f u u$ dan huruf 婦dibaca dengan $f u$ yang kemudian keduanya mengalami komposisi atau pemajemukan yang mewujudkan kata baru dengan identitas leksikal yang baru pula yaitu bermakna "pasangan suami-istri". Makna yang muncul merupakan makna baru yang berupa hubungan antara kedua kata pembentuknya.

Dapat kita amati bahwa terdapat hal menarik dari konstruksi fukugougo fuufu di atas yaitu mengenai terlebih dulu dituliskannya huruf yang memiliki makna "suami", baru kemudian disusul dengan huruf berikutnya yang memiliki makna "istri". Hal ini lah yang merupakan pengaruh dari konsep sosial budaya masyarakat Jepang terhadap pembentukan kata. Seorang suami yang merupakan seorang pria dan jugalah seorang kepala keluarga memiliki kekuasaan dan wewenang yang paling tinggi di dalam kelompok sosial terkecil yaitu keluarga. Seperti diungkapan oleh Minami (1993: 155) bahwa kekuasaan seorang ayah atau suami lebih besar daripada ibu atau istri dalam keluarga. Besarnya dominasi dan 216 | http://journal.unesa.ac.id/index.php/paramasastra 
Rizki Dwi Cahyo dan Masilva Raynox Mael, Konsep Sosial... (hlm. 210-222)

peran suami ini dikarenakan suamilah yang bertanggung jawab atas keluarganya dan suamilah yang mencarikan nafkah untuk keluarganya. Berbeda dengan zaman modern sekarang yang dimana wanita juga dapat bekerja setara dengan pria, dahulu wanita di Jepang hanya dianggap sebagai alat untuk kebangkitan negara, bukan sebagai manusia yang perlu mendapat perlakuan yang setara. Wanita hanya harus patuh pada suaminya, mengurus rumah, mengurus anak, dan mengurus orang tua yang sudah lanjut usia. Wanita juga dituntut untuk selalu menjaga kehormatannya. Wanita dianggap hanyalah sebagai alat untuk meneruskan garis keturunan saja, sehinngga suami memiliki hak dan wewenang paling besar dalam mengatur perihal dan urusan keluarga.

Berdasarkan lebih tingginya nilai martabat dan dominasi seorang suami atau kepala keluarga tersebutlah, kata fuufu terbentuk dengan kosntruksi kata "suami” berada di depan kata "istri”. Meskipun keduanya memiliki tataran yang sama dalam tataran fungsi sintaksisnya yaitu sama-sama sebagai nomina, namun kontruksinya dalam fukugougo tidaklah dapat dibalik atas dasar konsep sosial budaya yang ada.

\section{B. 兄弟 Kyoudai}

Kata majemuk ini terdiri dari huruf kanji 兄(ani) yang memiliki makna kakak laki-laki dan huruf 弟(otouto) yang bermakna adik laki-laki. Kata kyoudai ini merupakan fukugougo yang termasuk dalam variasi golongan sino-japanese compound karena kedua kata pembentuknya tidaklah dibaca dengan pelafalan bahasa Jepang asli melainkan dengan pelafalan cina atau onyomi nya. Kedua kata pembentuk fukugougo tersebut di atas mengalami proses komposisi yang kemudian menghasilkan kata dengan makna leksikal yang baru yaitu "saudara" 
atau "sepasang ssaudara laki-laki". Dapat dilihat bahwa makna yang dihasilkan berbeda dengan kata pembentuk, namun terdapat sebuah hubungan diantaranya.

Dapat diketahui dari pembentukan kata kouhai di atas dimana kata atau huruf 兄 ani dituliskan terlebih dahulu di depan kata atau huruf 弟otouto. Meskipun kedua kata pembentuk ini memiliki kedudukan yang sama dalam fungsi lingualnya namun kondisi struktur kata kyoudai tidaklah dapat dibalik, yaitu dengan mendahulukan kata otouto (adik laki-laki). Terdapat beberapa faktor yang mempengaruhinya yaitu salah satunya adalah faktor ikonik yaitu karena seorang kakak lahir terlebih dahulu daripada adik, namun selain itu hal ini juga dikarenakan kondisi sosial dan konsep keluarga di Jepang. Di Jepang seorang putra sulung memiliki hak dan kewajiban yang lebih daripada saudara-sauddara kandungnya yang lebih muda. Sistem keluarga di Jepang yang menganut paham patriarkal, sejak zaman meiji anak lelaki sulung memiliki hak lebih untuk mewarisi keluarga dan juga kewajiban untuk mengurus keluarganya nanti. Anak lelaki sulung haruslah mendapatkan prioritas lebih di dalam keluarga, anak sulung juga dituntut untuk menjadi orang yang pantas menjadi penerus keluarga. Saat orang tua telah meninggal dunia juga anak sulunglah yang mendapat lebih warisan harta orang tuanya.

Oleh karena itu, kata kyoudai terbentuk sedemikian rupa dengan kata ani (kakak laki-laki) dituliskan terlebih dahulu karena kondisi atau kedudukannya di dalam sistem keluarga Jepang yang lebih banyak perlu tanggung jawab dibandingkan dengan saudara kandung bungsunya.

\section{C. 親分Oyabun dan 子分Kobun}

Kata Oyabun memiliki makna "bagian orang tua" atau "bagian bapak" sedangkan kata kobun memiliki makna "bagian anak". Oyabun terdiri dari huruf 親yang bermakna “orang tua” dan 分yang bermakna “bagian”. Secara 
Rizki Dwi Cahyo dan Masilva Raynox Mael, Konsep Sosial... (hlm. 210-222)

keseluruhan gabungan kedua kata tersebut membentuk kata majemuk yang memiliki makna "bagian atau orang yang memiliki wewenang sebagai orang tua dan orang yang berkuasa dan bertanggung jawab atas anak atau bawahannya”. Sedangkan kata kobun terdiri dari huruf 子yang bemakna “anak" dan 分yang bermakna "bagian". Berkebalikan dengan oyabun, kobun memiliki makna "bagian yang berperan sebagai bawahan atau anak, yang loyal melayani dan menghormati pemimpinnya". Kedua fukugougo di atas termasuk ke dalam variasi kata majemuk hybrid compound karena keduanya memiliki konstruksi yang satu kata pembentuk dibaca dengan cara baca kunyomi (oya dan ko), sedangkan kata pembentuk lainnya dibaca dengan cara baca onyomi (pun).

Kata oyabun dan kobun sering digunakan di dalam kalangan mafia Jepang yaitu Yakuza. Oyabun merupakan pimpinan keluarga atau klan yang bertanggung jawab dan berhak memerintah seluruh bawahannya. Sedangkan kobun adalah anggota keluarga yang siap mengapdi apapun yang terjadi kepada oyabun. Hal ini menunjukan terdapat stratifikasi di kalangan masyarakat Jepang khususnya yakuza. Terbentuknya kedua kata tersebut adalah untuk menjaga jelasnya tingkatan yang ada dalam suatu kelompok sosial. Sehingga seluruh anggota kelompok sosial yang bersangkutan dapat bertindak dan bersikap sesuai dengan kedudukannya. Mempertahankan kepatuhan, penghormatan, dan disiplin kerja merupakan hal yang penting bagi masyarakat Jepang demi mempertahankan hidupnya.

Namun, kedua kata di atas tidaklah hanya digunakan di kalangan yakuza saja namun juga di dalam dunia perusahaan atau pekerjaan. Seperti suatu perusahaan besar ternama, memiliki anak-anak perusahaan kecil lainnya yang berfungsi sebagai pemroduksi barang. Bagi bangsa Jepang yang kental akan hubungan atas-bawah masyarakatnya, mempertahankan hal seperti ini adalah hal 
yang sangat penting demi menjaga moral dan keberlangsungan hidup masingmasing.

\section{D. 大丈夫Daijoubu}

Kata Majemuk Daijoubu terbentuk dari tiga huruf atau kata, yaitu 大 dai yang memiliki makna "besar", kata 丈jou yang bermakna, dan 夫 $f u$ yang memiliki makna "suami". Ketiga kata pembentuk fukugougo ini dibaca dengan menggunakan cara baca onyomi. Sehingga kata daijoubu termasuk ke golongan variasi kata majemuk sino-japanese compound dan memiliki makna secara keseluruhan "tidak apa-apa" atau "baik-baik saja". Dapat diketahui bahwa makna kata yang dihasilkan komposisi tersebut sangatlah tidak berhubungan dengan kata-kata pembentuknya. Tetapi, terbentuknya dan pemaknaan kata tersebut dapat dilihat dari konsep sosial budaya masyarakat jepang.

Dapat dilihat bahwa terdapat kata 夫yang bermakna "suami”. Diketahui pada pemaparan teori sebelumnya bahwa di Jepang masyarakatnya memiliki pola pikir yaitu pria merupakan manusia yang lebih unggul dan superior dari wanita. sehingga terdapat konsep pemisahan pekerjaan antara wanita dan pria. Pria bertanggung jawab melakukan pekerjaan yang membutuhkan tenaga dan kekuatan lebih sedangkan wanita hanya mengerjakan pekerjaan-pekerjaan rumah saja. Suami yang merupakan kepala keluarga memiliki wewenang penuh untuk mengatur keluarga, dapat dikatakan keputusan kepala keluarga lah yang dianggap terbaik.

Berdasarakan itu fukugougo daijoubu yang memiliki makna "baik-baik saja" ini terbentuk dari kata "suami", karena seorang kepala keluarga akan melindungi keluarganya, bekerja, dan mengatur keluarga sehingga semuanya berjalan baik -baik saja. 
Rizki Dwi Cahyo dan Masilva Raynox Mael, Konsep Sosial... (hlm. 210-222)

\section{E. 先輩. 後輩}

Dua fukugougo terdiri dari dua kata yaitu 先yang dibaca secara onyomi “sen" dan 後yang juga dibaca dengan onyomi (kou) dan masing-masing diikuti oleh kata 輩yang dibaca onyomi (hai). Kata sen memiliki makna "sebelum" dan kou bermakna "sesudah". Sedangkan hai memiliki makna "kawan". Kedua kata ini sama-sama termasuk dalam golongan sino-japanese compound yang kedua kata pembentuknya dibaca secara onyoumi dan secara literal senpai memiliki makna "kawan sebelum" dan kouhai memiliki makna "kawan setelah".

Secara keseluruhan senpai memiliki makna seseorang yang melakukan sesuatu atau masuk ke dalam suatu bidang terlebih dahulu, dan kouhai memiliki makna sebaliknya, yaitu melakukan atau memasuki suatu bidang kelompok lebih akhir. Sehingga kata ini merujuk kepada hubungan vertikal manusia Jepang terutama pada konsep senioritas. Hubungan senior dan yunior di Jepang sangatlah kental. Sudah seharusnya orang yang bergabung lebih dulu itu dihormati dan dipatuhi karena senior pastinya sudah lebih berpengalaman dibandingkan yunior. Masyarakat Jepang selalu berusaha untuk menjaga hubungan senioritas sebagai pembelajaran moral dan supaya tidak tersingkir dari posisi dalam kelompok sosialnya.

Dikarenakan senpai harus dihormati dan dprioritaskan maka saat kedua kata senpai dan kohai disandinkan menjadi satu majemuk senpaikohai, posisi kata senpai tidak lah dapat diletakan setelah kata kouhai meskipun tataran lingualnya sama karena akan bertentangan dengan nilai sosial budaya masyarakat yang berlaku di Jepang.

\section{SIMPULAN}

http://journal.unesa.ac.id/index.php/paramasastra | 221 
Asal pembentukan kata dalam sebuah bahasa tidaklah dapat semena-mena hanya dikaji dalam ilmu linguistik murni saja, namun juga perlu dikaji dari segi sosiolinguistik. Dikarenakan banyak sistem masyarakat yang berpengaruh dalam terbentuknya kata-kata dalam sebuah bahasa seperti, sistem stratifikasi, sistem keluarga, dan sistem jenis kelamin (gender) dan lain sebagainya. Di dalam buku minna no nihongo shokyuu terdapat 7 data kata majemuk bahasa Jepang yang penulis rasa terpengaruh oleh konsep sosial budaya masyarakatnya, yaitu terpengaruh sistem keluarga sebanyak dua buah data, terpengaruh sistem stratifikasi sebanyak tiga buah data, dan terpengaruh sistem gender sebanyak 2 buah data seperti yang sudah penulis paparkan sebelumnya. Masih banyak konsep sosial budaya lainya yang belum dapat penulis paparkan pada kesempatan kali ini dan mungkin dapat menjadi lahan pembahasan pemakalah-pemakalah sosiolinguistik lainya.

\section{DAFTAR RUJUKAN}

Chaer, Abdul. 2007. Linguistik Umum. Jakarta: Rineka Cipta

Minami, Hiroshi. 1993. Psikologi bangsa Jepang. Diterjemahkan oleh: Woekirsari, C. jakarta: Yayasan Karti Saena

Jayanti, Ni Wayan Eka. Tanpa tahun. "Variasi Komposisi Dan Makna Kata Majemuk (Fukugougo) Dalam Buku Kumpulan Esai Hitori Zumou Karya Sakura Momoko". Universitas Udayana.

Wijana, I Dewa Putu dan Muhammad Rohmadi. 2016. Sosiolinguistik: Kajian Teori dan analisis. Yogyakarta: Pustaka Pelajar.

Eri. Tanpa tahun. "Stratifikasi Sosial Masyarakat Jepang". Diambil dari http://eribolot.weebly.com/stratifikasi-sosial-masyarakat-jepang.html. $\quad$ (01 Juni 2017) 